\title{
ПОРІВНЯННЯ ВІТЧИЗНЯНОЇ ТА ЗАРУБІЖНОЇ (СВРОПЕЙСЬКОЇ) МОДЕЛЕЙ ЦІНОУТВОРЕННЯ В БУДІВНИЦТВІ
}

\section{COMPARISON OF NATIVE AND FOREIGN (EUROPEAN) MODELS OF PRICING IN CONSTRUCTION}

Войтович С. Я., магістр, Кислюк Д. Я., к.т.н., доцент, Ротко С.В., к.т.н., доцент, Ужегова О.А., к.т.н., доцент (Луцький національний технічний університет, м. Луцьк), Сиваченко Т.Л., інженер, УЧПП КБ "Промислові технології та комплекси", м. Могильов, Білорусь

Sergii Voitovych, Master, Dmytro Kyslyuk, Ph.D. in Engineering, Associate Professor, Svitlana Rotko, Ph.D. in Engineering, Associate Professor, Olha Uzhehova, Ph.D. in Engineering, Associate Professor (Lutsk National Technical University, Lutsk), Tatiana Sivachenko, engineer, Industrial technologies and complexes, Mohylov, Bilorus

У роботі, на основі теоретичного пошуку встановлено ступінь відповідності i диференціації вітчизняної та зарубіжної (європейської) моделей иіноутворення в будівництві. За результатами проведеного аналітичного дослідження здійснено порівняння структури елементів та їх питомої ваги у вартості будівельномонтажних робіт за вітчизняною та західною (європейською) методикою розрахунку кошторису.

Implementation of Ukraine to the European Union should provide the harmonization of the regulatory framework of construction and transition to the European model for calculating the cost of construction works.

That is why, the purpose of this scientific research is to establish the degree of correspondence and differentiation of the native and foreign (European) models of pricing in construction and determination of the specific weight and species recognition of its elements in the construction cost estimates of the facility.

The object of the research is the process of correspondence and differentiation of applied models (techniques) of cost formation for the construction works and the value of the specific element weight according to which such calculations are made; and the subject - theoretical search and analytical research of differentiation of both models of cost formation for the construction works and the value of the specific weight of the elements according to which such calculations are made.

It has been found out that both European and native models of the cost of construction works contain in their basis: direct costs (the cost of raw materials, the cost of wages, the cost of operating machinery and equipment); organizational and logistical costs; other costs. This in turn underlines their similarity concerning the elements which are taken into account at formation of the cost of construction works.

The calculation of the construction costs works by calculation technique has been revealed: the native model assumes the step-by-step accounting of the sum of direct 
expenses, the sum of general production expenses and other expenses, whereas the European model includes four components: direct expenses (connected with quantity of works), indirect expenses, risks and profitability, and also taxes and fees. Calculation of this cost is carried out by taking into account the weighting coefficients for different types of construction works, different values of such works and the like.

The analysis of the structure of the estimate of construction and installation works (based on manual works of performed cement-lime plastering or cement mortar on concrete walls per $100 \mathrm{sq}$. meters) by native and foreign methods of estimate calculation has shown structural differentiation of specific weight and kinds of elements of the estimate.

Ключові слова: моделі ціноутворення в будівництві, диференціація вітчизняної та європейської моделей розрахунку вартості будівельних робіт щуодо методики калькулювання, елементи структури кошторису будівельно-монтажних робіт, питома вага елементів у комторисній вартості об' єкту будівництва.

Keywords: models of pricing in construction, differentiation of the native and European models of calculation of the construction works cost, elements of the estimate of construction and installation works, specific weight of elements in the estimated cost of the construction objects.

Аналіз досліджень та постановка задачі. Цілями даного наукового дослідження $є$ порівняння моделей (методик) формування вартості будівельних робіт за кордоном (європейський досвід) та в Україні з метою гармонізації вітчизняної кошторисно-нормативної бази ціноутворення в будівництві із аналогічною у Свропейському союзі.

Метою наукового дослідження є встановлення ступеня відповідності та диференціації вітчизняної та зарубіжної (європейської) моделей ціноутворення в будівництві та встановлення величини питомої ваги і видової ознаки його елементів у кошторисній вартості об'єкту будівництва.

Постановка завдання. Реалізація поставленої у дослідженні мети визначила необхідність вирішення наступних завдань:

- дослідження західної моделі (методики) формування вартості будівельних робіт;

- дослідження вітчизняної моделі (методики) формування вартості будівельних робіт;

- порівняння структури елементів та їх питомої ваги у вартості будівельно-монтажних робіт за вітчизняною та західною (європейською) методикою розрахунку кошторису.

Виклад основного матеріалу. Важливе значення в процесі передпроєктної, проектної стадії та у процесі виконання будівельних робіт має ціноутворення у будівництві, від якого залежать не лише ціна об'єкту будівництва, терміни виконання будівельних робіт, залучення інших організацій до виконання окремих робіт, але й інвестиційна складова щодо реалізації проекту будівництва. 
Виходячи 3 цього, необхідно вивчати досвід кращих компаній та зарубіжний досвід щодо використання методик ціноутворення та практик встановлення вартості будівельних робіт 3 метою їх застосування в Україні.

Дослідження західної (європейської) моделі формування вартості будівельних робіт дає змогу ствердити, що в основі такої моделі лежить методика ціноутворення на основі врахування вартості основних елементів, що визначають самі будівельні роботи, використання ресурсів, врахування доходності та ризиків (рис.1) [1;2; $;$; 5 с. 81].

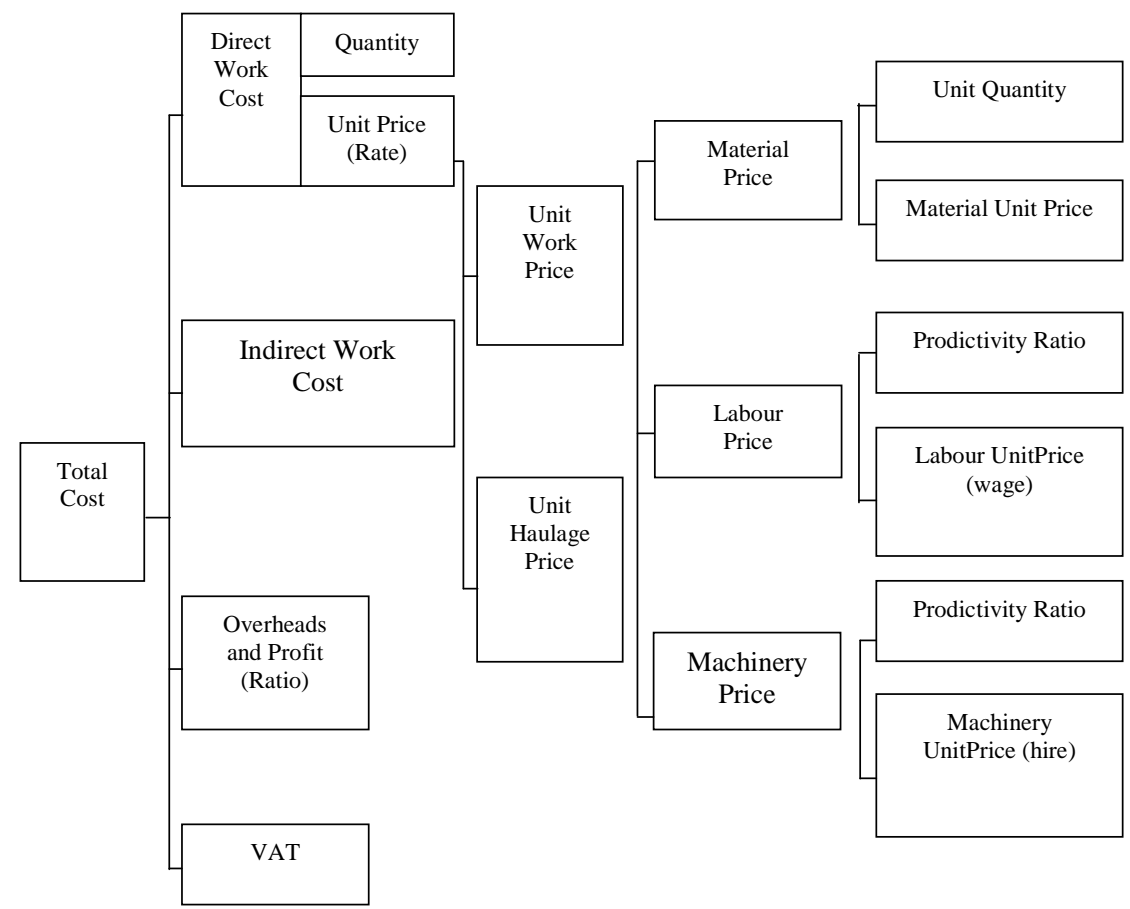

Рис. 1. Формування вартості будівельно-монтажних робіт (західна (європейська) модель)

Отже, загальна вартість будівельних робіт (ТC) включає в себе чотири складові: прямі витрати (UP) які пов'язані із кількістю робіт (Q), непрямі витрати (IWC), ризики та рентабельність (OP), а також податки i збори (VAT). 
Так, прямі витрати пов'язані із використанням вартості трудових ресурсів, матеріальних ресурсів та основних засобів, тобто знарядь праці.

Врахування зазначених складових у вартості будівельних робіт, 3 однієї сторони визначає повноту врахування застосовуваних ресурсів, ризиків та врахування планових величин результативності підприємств щодо реалізації будівельних робіт, тощо. 3 іншого боку - вартість оцінюється шляхом врахування вагових коефіцієнтів щодо різних видів будівельних робіт, різної величини таких робіт і т.д.

Західна модель формування вартості будівельних робіт, таким чином, може бути описана (формула 1):

$$
\mathrm{TC}=\mathrm{SUMM}(\mathrm{QxUP}) \mathrm{x}(1+\mathrm{IWC}) \mathrm{x}(1+\mathrm{OP}) \mathrm{x}(1+\mathrm{VAT})
$$

Запропонована формула розрахунку вартості будівельних робіт грунтується на вищезазначеній методиці формування вартості будівельних робіт та включає вищеперераховані складові. При цьому, сама величина складових та методики їх обрахунку є диференційованими щодо видів будівельних робіт, їх організації, результативності, тощо.

В Україні функціонує вітчизняна модель розрахунку кошторису будівельно-ремонтних робіт та ціноутворення в будівництві (рис. 2) [6; 7; $8 ; 9$, c. $124 ; 10]$.

Так, кошторисна вартість будівництва визначається наступною методикою (формула 2): прямим сумуванням вартості будівельних робіт, вартості монтажних робіт, вартості технологічного устаткування та інших витрат [6].

$$
\mathrm{V}_{\bar{\sigma}}=\mathrm{V}_{\text {бр }}+\mathrm{V}_{\text {мпр }}+\mathrm{V}_{\mathrm{y}}+\mathrm{V}_{\text {ін }}
$$

де $\mathrm{V}_{\text {б }}$ - вартість будівельної продукції,

$\mathrm{V}_{\text {бр }}$ - вартість будівельних робіт,

$\mathrm{V}_{\text {мр }}$ - вартість монтажних робіт,

$\mathrm{V}_{\text {y }}$ - вартість технологічного устаткування,

$\mathrm{V}_{\text {iн }}-$ інші витрати.

Кошторисна вартість будівельно-монтажних робіт згідно даної методики розраховується сумуванням прямих і загальновиробничих витрат (формула 3):

$$
\mathrm{V}_{\text {БMР }}=\mathrm{V \Pi}+\mathrm{V} 3 \mathrm{~B}
$$

де VП - прямі витрати,

VЗВ - загально виробничі витрати. 


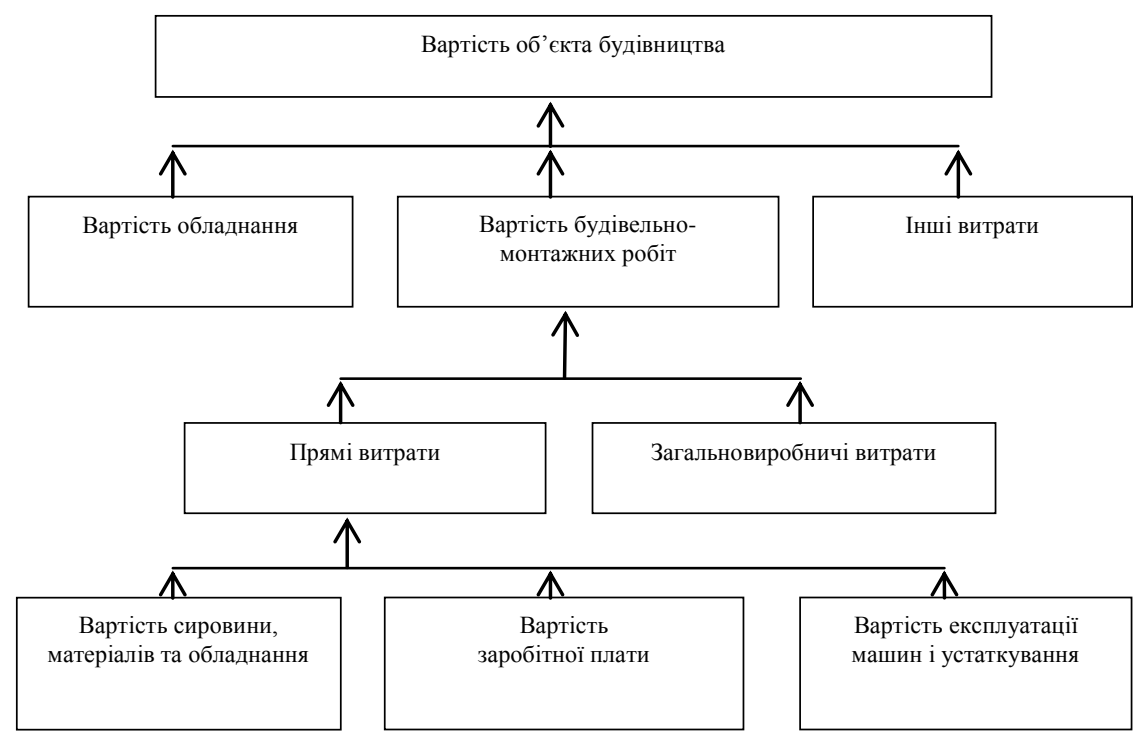

Рис. 2. Формування вартості будівельно-монтажних робіт (вітчизняна модель)

Прямі витрати в свою чергу враховують: заробітну плату робітниківв виконавців, вартість експлуатації машин, механізмів та обладнання, вартість сировини, виробів та матеріалів, конструкцій.

Загально-виробничі витрати включають в себе: витрати на управління та обслуговування будівельного виробництва чи ремону, витрати на організацію і обслуговування будівельного майданчика та вдосконалення будівельної технології.

Структура кошторису будівельно-монтажних робіт (поліпшене штукатурення цементно-вапняним або цементним розчином по каменю i бетону стін вручну на $100 \mathrm{~m}^{2}$ ) за вітчизняною методикою розрахунку кошторису здійснено на основі застосування ПК АВК 5.

Вагомість окремих елементів кошторису у загальній вартості будівельних робіт за вітчизняною методикою обрахунку представлена на рисунку 3.

Диференціація моделей (методик) обрахунку кошторису будівельномонтажних робіт в Україні та за кордоном визначає необхідність дослідження структурно-видової вагомості окремих елементів кошторису у загальній вартості будівельних робіт. 


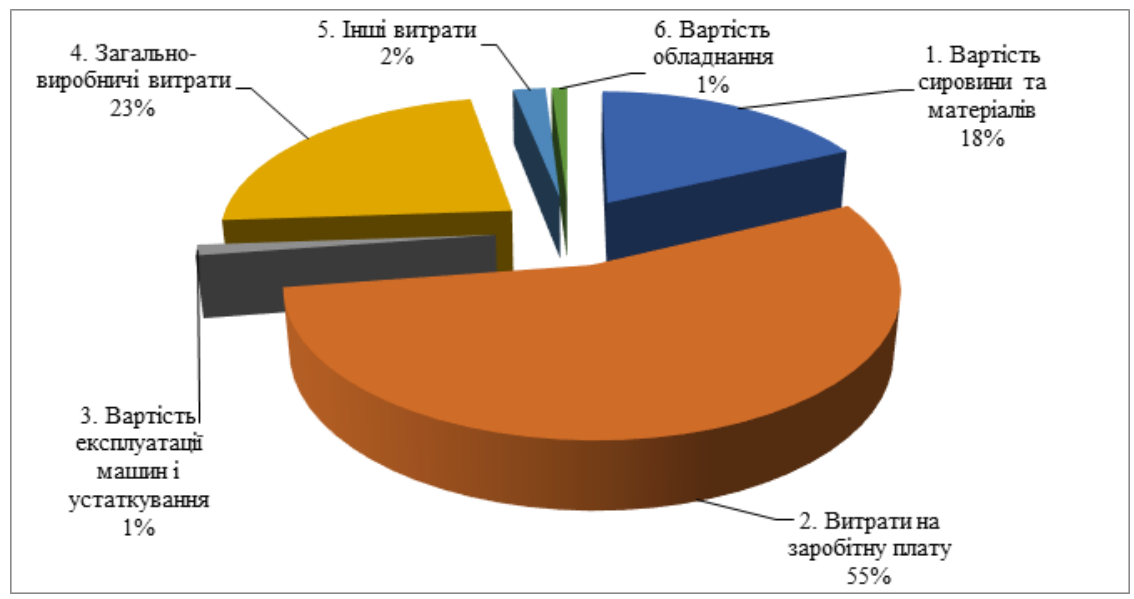

Рис. 3. Структура кошторису будівельно-монтажних робіт

(поліпшене штукатурення цементно-вапняним або цементним розчином по каменю і бетону стін вручну на $100 \mathrm{~m}^{2}$ )

за вітчизняною методикою розрахунку кошторису, \%

Вагомість окремих елементів кошторису у загальній вартості будівельних робіт за зарубіжною (європейською) методикою обрахунку представлена на рисунку 4.

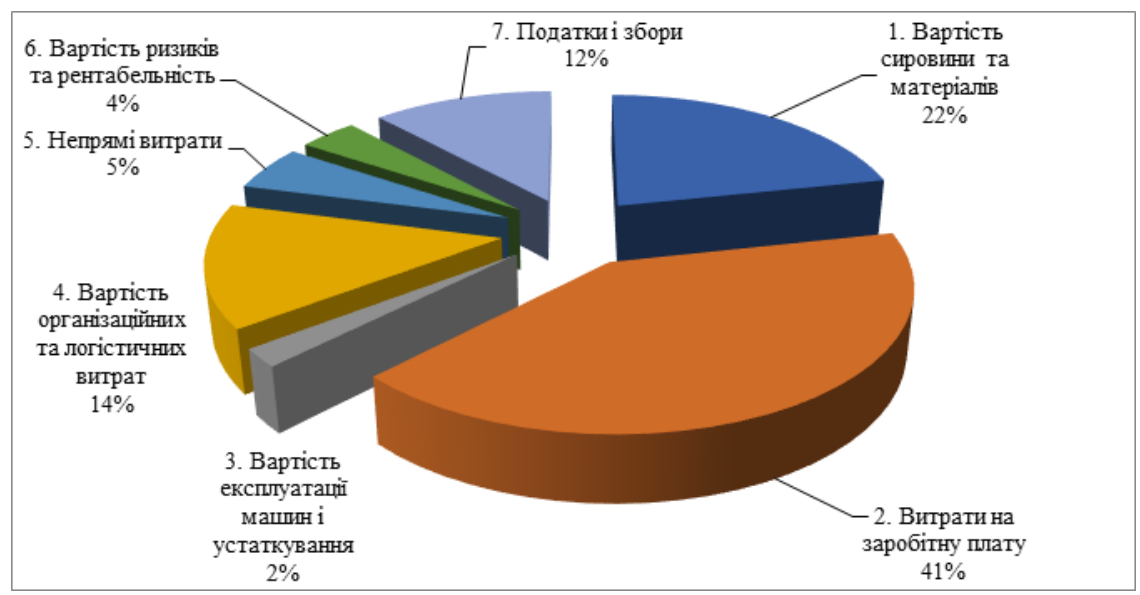

Рис. 4. Структура кошторису будівельно-монтажних робіт (поліпшене штукатурення цементно-вапняним або цементним розчином по каменю і бетону стін вручну на $100 \mathrm{~m}^{2}$ )

за західною (європейською) методикою розрахунку кошторису, \% 
Проведений аналіз структури кошторису будівельно-монтажних робіт (поліпшене штукатурення цементно-вапняним або цементним розчином по каменю і бетону стін вручну на $100 \mathrm{~m}^{2}$ ) за вітчизняною та західною методиками розрахунку кошторису показав структурну диференціацію щодо питомої ваги та видової ознаки елементів кошторису.

Висновки за результатами досліджень. Проведене у роботі теоретичне узагальнення сутності вітчизняної i зарубіжної моделей ціноутворення та аналітичне дослідження структури елементів та їх питомої ваги у вартості будівельно-монтажних робіт за вітчизняною та західною (європейською) методикою розрахунку кошторису дозволило сформувати наступні висновки.

1. Як європейська, так і вітчизняна моделі формування вартості будівельних робіт у своїй основі містять: прямі витати (витрати на сировину і матеріали, витрати на заробітну плату, витрати на експлуатацію машин і устаткування); організаційні та логістичні витрати; інші витрати. Це в свою чергу підкреслює їх подібність щодо елементів, які беруться до уваги при формуванні вартості будівельних робіт.

2. Досліджувані моделі розрахунку вартості будівельних робіт різняться між собою насамперед методикою калькулювання: вітчизняна модель передбачає поетапне врахування суми прямих витрат, суми загально-виробничих витрат та інших витрат, тоді як західна - включає в себе чотири складові: прямі витрати (пов'язані із кількістю робіт), непрямі витрати, ризики та рентабельність, а також податки і збори. Розрахунок зазначеної вартості здійснюється шляхом врахування вагових коефіцієнтів щодо різних видів будівельних робіт, різної величини таких робіт і т.д.

3. Проведений у роботі аналіз структури кошторису будівельномонтажних робіт (поліпшене штукатурення цементно-вапняним або цементним розчином по каменю і бетону стін вручну на $100 \mathrm{~m}^{2}$ ) за вітчизняною та західною методиками розрахунку кошторису показав структурну диференціацію щодо питомої ваги та видової ознаки елементів кошторису.

4. Імплементація України до Свропейського Союзу повинна передбачати у тому числі гармонізацію нормативної бази будівництва та перехід на європейську модель розрахунку вартості будівельних робіт.

\section{References}

1. EN 1992 Eurocode 2: Design of concrete structures.

2. EN 206 Concrete: Specification, performance, production and conformity.

3. EN 1365 Test methods for fire resistance of load bearing elements.

4. EN 1090 Execution of steel structures - Technical requirements.

5. Thomas Telford. CESMM3: Civil Engineering Standard Method of Measurement. Institution of Civil Engineers (Great Britain).1991. 
6. Berkuta A.V. Reformuvannya tsinoutvorennya u budivnytstvi: zavdannya, napryamy, problemy // Ekonomika Ukrayiny. 2002. № 2. S. 4-9.

7. Reznychenko V.S., Lenyntsev N.N. Systemnyy podkhod k sovershenstvovanyyu tsenoobrazovanyya y upravlenyya stoymost'yu v stroytel'stve // Ékonomyka stroytel'stva. - Kommunal'noe khozyaystvo horodov. 2014. № 5. S. 50-61.

8. Nikoloyev V.P. Novi zasady tsinoutvorennya $\mathrm{v}$ investytsiyno-budivel'nomu protsesi// Formuvannya rynkovykh vidnosyn v Ukrayini. 2010. №4. S. 71-77.

9. Pinishko V.S. Tsiny i tsinoutvorennya: Navch. posibnyk. - L'viv. : IntelektZakhid, 2016. $488 \mathrm{~s}$.

10. Kyrylenko V., Kyrylenko L. Teoryya tseny y sovremennoe tsenoobrazovanye v Ukrayne // Ekonomyka Ukrayny. 2012. № 8. S. 56-62.

\section{Список використаних джерел}

1. EN 1992 Eurocode 2: Design of concrete structures.

2. EN 206 Concrete: Specification, performance, production and conformity.

3. EN 1365 Test methods for fire resistance of load bearing elements.

4. EN 1090 Execution of steel structures - Technical requirements.

5. Thomas Telford. CESMM3: Civil Engineering Standard Method of Measurement. Institution of Civil Engineers (Great Britain).1991.

6. Беркута А.В. Реформування ціноутворення у будівництві: завдання, напрями, проблеми // Економіка України. 2002. № 2. С. 4-9.

7. Резниченко В.С., Ленинцев Н.Н. Системный подход к совершенствованию ценообразования и управления стоимостью в строительстве // Экономика строительства. - Коммунальное хозяйство городов. 2014. № 5. С. 50-61.

8. Ніколоєв В.П. Нові засади ціноутворення в інвестиційно-будівельному процесі// Формування ринкових відносин в Україні. 2010. №4. С. 71-77.

9. Пінішко В.С. Ціни і ціноутворення: Навч. посібник. - Львів. : ІнтелектЗахід, 2016. 488 с.

10. Кириленко В., Кириленко Л. Теория цены и современное ценообразование в Украине // Економика Украины. 2012. № 8. С. 56-62. 